\title{
Atrocity Crimes and the Search for Justice in Sudan: Why ICC Must Not Relent
}

James E. Archibong*

Department of Jurisprudence and International Law, Faculty of Law, University of Calabar, Nigeria

DOI: $10.36348 /$ sijlcj.2021.v04i03.003 $\quad$ | Received: 25.02.2021 | Accepted: 02.03.2021 | Published: 15.03 .2021

*Corresponding author: James E. Archibong

\section{Abstract}

In 2003, Sudan joined the ignoble league of States disparaged for monstrous crimes against their citizens. The administration of Omar al-Bashir quickly garnered notoriety for genocide, war crimes and crimes against humanity perpetrated against the people of Darfur. Upon a UN Security Council referral, the International Criminal Court (ICC) made a futile attempt to arrest five persons most responsible for the atrocities. Following the fall of al-Bashir in 2019, there has been renewed zeal to ensure accountability for perpetrators and justice for the victims of those crimes. The Sovereign Council, Bashir's successor, has so far failed to deliver on this, despite promises. The UN Security Council has so failed to render any assistance to secure their arrest. Hope for accountability and justice now rests on the implementation of ICC's subsisting indictments and warrant of arrest and it cannot afford to fail.

Key words: Atrocity crimes, Sudan, accountability, justice, Darfur, ICC.

Copyright (C) 2021 The Author(s): This is an open-access article distributed under the terms of the Creative Commons Attribution 4.0 International License (CC BY-NC 4.0) which permits unrestricted use, distribution, and reproduction in any medium for non-commercial use provided the original author and source are credited.

\section{INTRODUCTION}

Atrocity crimes are egregious or core crimes of global concern [1]. Embedded in international crimes, and defined in major international instruments, they are typified by genocide, war crimes, and crimes against humanity. The issue of international crime came to limelight during the Second World War, and was given a judicial definition in 1948 to be grievous; universally identified as criminal; and open to prosecution by any state (Hostage Case, United States v List (Wilhelm) and ors, Trial Judgment, Case 7, (1948) 11 TWC 757)). Atrocity crimes did not end with the Second World War, but continued in subsequent conflicts. Such crimes were prevalent during the Vietnam War [2] and the Korean War [3]. The armed conflict in the former Yugoslavia marked a turning point in the international community's perception of such crimes, and the need to curb impunity associated with them. This culminated in the creation of the International Criminal Tribunal for the former Yugoslavia in 1993 and the International Criminal Tribunal for Rwanda in 1994. Other ad hoc tribunals instituted to address impunity and individual criminal responsibility during conflict include the Special Court for Sierra Leone, the Extraordinary Chambers in the Courts of Cambodia and the Special Panels for Timor-Leste [4]. The Rome Statute was adopted in 1998, ushering in the first permanent international criminal court.

Sudan has been at crossroads since independence in 1956, entangled in a web of violence [5]. The ascension to power of Omar al-Bashir in 1989 brought about a glimmer of hope of return to peace. That was not to be as the violence escalated under his watch. In 2003, a military campaign ordered by $\mathrm{Mr}$. Bashir was launched by Sudanese government forces and allied militias in the western region of the country, known as Darfur, to quell a rebellion by the mainly black African inhabitants of the area [5]. For nearly two decades, the Darfur region of Sudan was plagued by armed conflict between government forces and opposition armed groups [7]. Atrocity crimes had allegedly been committed primarily by government forces and their allies. To a lesser extent, armed opposition groups, dominated by the Sudan Liberation Movement/Army (SLM/A) and the Justice and Equality Movement (JEM) have also been implicated in serious crimes. While the conflict persisted, international press was awash with accounts of war crimes, crimes against humanity and genocide perpetrated against the people of Darfur. Scorched-earth policy was adopted by the military and their allies resulting in an estimated 
James E. Archibong., Sch Int J Law Crime Justice, Mar, 2021; 4(3): 144-150

300,000 civilian deaths, and about 2.5 million people displaced. Belligerents burned down and pillaged villages [8]. Thousands of women were raped and subjected to sexual violence. In the course of the conflict war crimes, crimes against humanity and genocide were allegedly perpetrated in the region.

Five prominent Sudanese individuals were found culpable for the atrocities perpetrated against Darfur civilians and their property, but have been out of the reach of justice since their indictment by the International Criminal Court [9]. The ousting of Omar al-Bashir from power has reignited the debate apropos accountability and justice in Sudan. It has created an opening for perpetrators to answer for those crimes and come clean, and for the victims to have justice and closure [10]. The campaign to make the five men wanted by the ICC face justice has gathered momentum. But whether this will happen only time will tell.

This paper interrogates the conflict in Sudan, the atrocity crimes committed by the warring sides and the indictments issued by the ICC. It also examines the refusal of the transitional government in Khartoum to surrender the culprits in their custody for trial. It argues that the international community, led by the United Nations Security Council [46], should seize this golden opportunity to bring justice to the thousands of victims of Darfur crimes. This will send a strong message to war criminals that their actions will not go unpunished, as well as prove a significant point that the ICC does not only bark, it can also bite.

\section{The conflict in Darfur and gross human rights violations}

The armed conflict in Sudan which was the first in post-colonial Africa began with the Torit Mutiny of 1955, a few months before independence [12]. The government reaction to the grievances was harsh and coercive [11]. The second conflict which marked the rise of resistance movements is often regarded as an elongation of the first [13]. Lieutenant-General Omar Hassan Ahmad al-Bashir and his Revolutionary Command Council of National Salvation became the beneficiaries of over three decades of civil strife and instability. He was one of the top commanders in the Sudanese army, specifically entrusted with the task of decimating the southern rebel forces led by John Garang. His tenure was dictatorial, oppressive and characterized by gross human rights abuses [14]. One of the factors that influenced his assumption of political leadership was the promise to end war. In 2005, the Bashir administration signed an agreement to wrap up the conflict [15]. This however did not bring the much needed peace to Sudan. Rather than usher in peace another front opened in the western region of the country known as Darfur.
The hostilities in Darfur recorded great brutality and suffering and took a huge toll on civilians [16]. The crimes were characterized by attacks on civilians in Darfur and plundering of towns and villages. The elements of genocide were typified by decimation of members of the Fur, Masalit and Zaghawa ethnic groups.

The crimes against humanity were epitomized by murder, extermination, forcible transfer, rape and torture. Government security forces working with the Janjaweed, a state-sponsored militia group, bear responsibility for most of the atrocities [17]. They ravaged villages killing the men, raping the women and looting and striping the territories of their valuables. Bashir also took his campaign of violence to the people of Nubia Mountains [18].

Human rights organisations alleged that the Bashir administration used scorched earth policy to rip the region of its population [8]. The regime of reduced villages in Darfur to rubble and wasteland through aerial bombardment, torching of houses, pillage and extensive rape of women and girls [8]. The district of Jebel Marra sustained colossal destruction and adverse consequences from the Sudanese government fire power [19]. Side by side with the organized destruction of houses and villages was the methodical theft of cattle and livestock. It was observed that periodically most of these villages or their remnants were re-torched to serve as a reminder to fleeing residents that they should never contemplate a return [20]. Chemical weapons were also reportedly used in the onslaught by the Sudanese armed forces, an allegation the Foreign Minister described as 'nonsense' [19]. The conflict dragged in the African Union (AU) and the United Nations (UN), both institutions working frantically to enthrone peace in the region.

\section{UN referral of the situation in Sudan}

The crimes perpetrated in Darfur were brought to the attention of the United Nations Security Council, following the Report of the International Commission of Inquiry on Darfur (pursuant to Security Council Resolution 1564 of 2004 [47]. In 2005 the UN Security Council adopted Resolution 1593 [22], referring the situation in Sudan to the ICC [23]. This was followed by imposition of arms embargo on Sudan along with travel ban and asset freeze against certain individuals in 2006. The referral was a partial victory for the ICC considering its rejection by the United States and some major powers in the 15-member Council. Eleven States voted in support of the resolution, not one against, and four comprising Algeria, Brazil, China and United States abstained [24]. The resolution also enjoined all parties to the conflict to render unqualified cooperation and assistance to the Court. In 2005, the Court launched investigation into crimes committed in Sudan 
James E. Archibong., Sch Int J Law Crime Justice, Mar, 2021; 4(3): 144-150

notwithstanding Sudanese government denunciation and lack of cooperation. Sudan had opposed the referral, contending that it was not a member of the ICC.

\section{The five men wanted by ICC}

The Court indicted Mr. al-Bashir for war crimes and crimes against humanity [9] and issued a warrant for his arrest (The Prosecutor v Omar Hassan Ahmad al-Bashir ICC-02/05-01/09). Later, the charge of genocide was slammed on him. Other individuals indicted by the Court are Abdel Raheem Hussein, Ahmad Harun, Ali Kushayb and Abdallah Banda, which issued warrants for their arrest. Abdel Rahim Mohammed Hussein was the Minister of National Defence of the Republic of Sudan. He also served for a period as the Minister of Interior Affairs and President's Special Representative in Darfur. He was charged by the ICC for war crimes and crimes against humanity [25]. On 1 March, 2012, the ICC issued a warrant for his arrest (The Prosecutor v. Abdel Raheen Muhammed Hussein ICC-02/05/12). He was arrested in early April 2019 following a coup on 11 April which overthrew alBashir.

Ahmad Mohammed Harun is wanted for war crimes and crimes against humanity (The Prosecutor v Ahmad Muhammed Harun). He served from 2003 to 2005 as Minister of State for the Interior of Sudan. Ali Kushayb is charged with war crimes and crimes against humanity as the alleged commander of the Janjaweed militia, which allegedly implemented the Sudan government's counter-insurgency strategy in Darfur from 2003-2004. Abdallah Banda was the Commanderin-Chief of the Justice and Equality Movement (JEM). $\mathrm{He}$ is wanted for three counts of war crimes allegedly committed during the Haskanita raids against African Union peacekeepers within the context of the Darfur conflict in Sudan (The Prosecutor v. Abdallah Banda Abakaer Nourain ICC-02/05-03/09). Unfortunately, these individuals evaded arrest for several years. The overthrow of al-Bashir in April, 2019 provided a new impetus for their arrest and trial. On 9 June, 2020 Ali Kushayb the militia commander responsible for implementing Sudan government's counter-insurgency strategy in Darfur from 2003-2004, surrendered and was taken into ICC custody [26].

\section{Why Sudan suspects must be surrendered to the ICC}

In peace talks with various armed groups, the government agreed to hold members of the Bashir administration accountable for all crimes committed against the people of Sudan [27]. In February, 2020 the prime minister and head of the Sovereign Council reaffirmed their commitment to cooperate with the ICC [25]. The authorities announced that suspects indicted by the ICC for crimes committed in Darfur region would face trial in The Hague. This decision is significant for Sudan, the ICC and the international community for the following reasons.

In order to heal the wounds occasioned by the conflict, it is imperative to hasten the arrest and trial of the culprits. The civil war in Sudan had been characterized by tremendous shedding of innocent blood. Everlasting wounds and scars have attended the conflict. In order to move forward, the wounds need genuine healing. The principal balm for healing of such wounds and providing closure is accountability. Perpetrators in the conflict must accept their role in the cruelty and properly atone for their sins. Mohammed Hassan al-Taishi of the ruling council remarked that "we can only achieve justice if we heal the wounds with justice itself" and it is a reality the people of Sudan cannot run away from [28].

It is the popular demand of the Sudanese people that perpetrators of atrocity crimes in Darfur should face the ICC. The military government that took power initially said it would not deliver up Mr. alBashir to the ICC. This position was subsequently changed. The people who took to the streets for months against his tyrannical rule, which eventually led to his downfall, pressured the ruling authority to ensure that he is tried abroad for the brutality and horrendous crimes perpetrated in Darfur in particular and the country in general. Under heat from the protest movements, the authorities have promised to consider his extradition [29]. This is an explicit clue that the civilian members of the ruling council want to see them face international justice. The potential extradition is compatible with the desire of the majority of Sudanese [29]. There are widespread vocal demands from the Sudanese for justice and accountability. In Darfur women kept vigil to commemorate massacres [30]. A sit-in in the town of Nertiti has grown as people across the country rally behind demands for security and justice [26]. The sit-in has received widespread solidarity from pro-democracy protesters all over Sudan and abroad.

Putting them on trial is the right step towards peace. The adversaries in the conflict are currently searching for peace, hence the consultations and negotiations concurrently going on across the country. It should be pointed out that genuine search for peace must be accompanied by accountability. Amnesty International [30] said that surrendering him to the Court would mark an obliging start on the road to justice for victims and their families. The prosecution of al-Bashir and other indicted persons by the ICC will create a suitable atmosphere for genuine peace and reconciliation. 
James E. Archibong., Sch Int J Law Crime Justice, Mar, 2021; 4(3): 144-150

Trial at the ICC will redeem the image and credibility of the Court. Since it commenced trial on I July, 2002, the image and credibility of the Court has been tainted seriously. It has been smeared with criticism of diverse dimensions. African leaders accuse it of bias and double standard. The United States sees it as an illegal entity. Other big nations like Russia, Israel and Turkey reject the Court in its totality [31]. The Court has not been able to try cases outside of Africa. Some of its high profile cases ended in disarray. Failure to arrest the former president undermines the Court's integrity and credibility [9]. Bashir's acts of temerity have deeply tarnished the credibility of the ICC [32]. Thus the Court has a lot to do to redeem its image, acceptability and credibility [33]. The ex-tyrant could finally face justice, but where and when that might happen remains unresolved [32]. If it happens, it will whittle down the culture of impunity that emboldens despots everywhere [32]. In this regard, the successful prosecution of al-Bashir is an acid test for the Court.

It will ensure justice for the victims and their families. Criminal prosecution is not only about punishment of perpetrators, but also justice for the victims. The victims of atrocities in Darfur deserve justice. Thus the proposed handover and prosecution of the deposed president should be regarded as a necessary move for justice [21].

The prosecution of al-Bashir and other wanted men at the ICC will mark an end to an era of impunity that spanned 30 years. The country had descended into an arena of impunity and was listed as one of the global sponsors of terrorism. It earned a pariah status and suffered international isolation for prompt and violent suppression of internal dissent. It will therefore be memorable as well as extinguish a generation of impunity to have him face his accusers and victims in court. As Amnesty International [21] posits, the transitional government should strive beyond mere promises and take concrete action to extradite him and other persons wanted by the Court. It should demonstrate that the days of impunity are surely over and that individuals in the erstwhile regime responsible for horrendous crimes face justice [21]. The surrender of al-Bashir would be a major step towards confronting longstanding impunity for human rights abuses under Bashir as well as bring victims closer to justice [34].

Omar al-Bashir and four other culprits have been fugitives for more than a decade, enjoying their right to freedom of movement, and without fear of arrest. It is important to state that not putting al-Bashir on trial at an international court will send a wrong message to other fugitives that they can escape justice by simply evading arrest. Another serious implication is that failure of States to arrest al-Bashir and other fugitives at large will encourage continued violations of the Rome Statute [4].

It is an international scandal that they have escaped justice and accountability for so long. The fact that al-Bashir and other indicted persons have forged ahead to defy the global community should be perceived as an affront to international law and justice. It is a let-down to thousands of their victims [30]. States that signed up to the Rome Treaty are under international duty to apprehend them should they enter their territories [30]. However, several ICC member States have declined to arrest him on their soil on the flimsy argument that he was a sitting Head of State and enjoyed immunity [35]; and therefore could go scot-free with mass murder. The time has come for him to answer for those crimes, having joined the ignoble club of deposed leaders.

States parties are duty-bound to arrest the fugitives and transfer them to the ICC. So far they are unwilling to cooperate with the Court. In 2015 the South African government disobeyed a court order to detain him when he visited Johannesburg to attain a summit of the AU. The court thereafter described the government's action as 'disgraceful' [36]. The refusal to arrest him was also described as a disservice and betrayal of Mandela's ideals and legacy [37]. Along the line, South Africa initiated a debate on withdrawal of its membership from ICC following the criticism of its refusal to arrest al-Bashir [38]. In the event of a State party's refusal to carry through an arrest, it can be reported to the UN Security Council and the Assembly of State Parties (ASP). The call by the AU on member States not to cooperate in apprehending him violates States Parties' obligations to collaborate with the Court as enshrined in the Rome Treaty [39].

Sudan is under a duty to work with and assist the ICC due to the nature of crimes under consideration. The country signed the Rome Statute on 8 September, 2000, but without ratification [40]. It is immaterial that it has not yet ratified the treaty as prosecution of heinous crimes forms part of customary international law. Beyond the ICC, States are empowered to apprehend and try their perpetrators under the principle of universal jurisdiction.

\section{Responsibility to protect: UN's failure to confront impunity}

Responsibility to protect (R2P) is a vital global concept, universal norm and solemn commitment adopted in 2005 (UN World Summit Outcome Document) that seeks to protect society from heinous crimes such as genocide, war crimes, crimes against humanity and ethnic cleansing [41]. It is a fall-out of the massacre in Rwanda and former Yugoslavia and the 
James E. Archibong., Sch Int J Law Crime Justice, Mar, 2021; 4(3): 144-150

inaptitude of the international community to react appropriately [42].

The UN Security Council is vested with responsibility to maintain international peace and security. Since the referral of Sudan to the ICC, the Council has not shown any interest in the apprehension and prosecution of al-Bashir. The lead prosecutor at ICC observed and rightly told a divided UN Security Council that for justice to be implanted in Darfur, the copious acts of impunity must be halted. She wondered why and how persons accused of horrific crimes could enjoy unrestrained freedom of movement around the world [24]. It is baffling how persons being sought by the Court in relation to heinous crimes could undertake foreign trips freely [24].

The problem with the Security Council has been its polarized posture towards the Sudan crisis [43]. The UN force deployed there was weak, ineffective and incapable of protecting civilians. The Sudanese authorities denied UN personnel access to several areas where serious violations took place. Amid the escalating violence and perceived UN inertia, former Secretary General, Kofi Annan, described the Darfur crisis as "a crucial test for the Council's authority and effectiveness" [44]. Of course the UN failed the test on protection of vulnerable people as it is failing that of accountability. On 19 June, 2019, ICC Prosecutor, Fatou Bensouda called for the support of the UN Security Council and the transitional government in Sudan to ensure accountability and justice for victims [34].

The Council is vested with the mandate to maintain international peace and security, and is endowed with capacity and mechanisms to ensure that member States of the UN apprehend suspects wanted by the Court in relation to the crimes in Darfur. It has so far failed to act on the numerous reports of noncompliance referred to it [24]. The Security Council declined to respond emphatically to protect civilians and prevent gross human rights transgression in Bosnia and Rwanda [45], thereby bit by bit eroding its authority and legitimacy [40]. Failure of the Council to act portends danger in the campaign to end impunity in conflict [23, 48, 49].

\section{CONCLUSION}

Thousands of people have been slaughtered in Darfur since 2003. Following the indictment of the former president and four others by the ICC, the transitional administration promised to implement the arrest warrants issued against them. So far, it has failed to extradite those in its custody to the court. As the country searches for justice, the government has reaffirmed its commitment to cooperate with the ICC. Despite an open declaration that it would pursue justice and accountability against perpetrators of international crimes, it is not clear when that will happen. The government appears to be treading with caution. It is very discouraging that so much efforts and resources had been committed since 2005 with very little progress to show for it.

Justice may take a long time to achieve and often requires political courage. In that regard, there is need for collective action to achieve success. In her address to the UN Security Council, ICC Prosecutor, Fatou Bensouda, said tangible action must be taken towards ending impunity for atrocity crimes in Darfur; and wished the government would respect its assurances to deliver justice for the victims of the conflict. The UN Security Council has a duty under international law to act to protect populations from monstrous crimes. Respect for human rights must incorporate readiness to guarantee accountability. As Sudan undergoes transition, it is submitted that genuine peace and reconciliation cannot be attained without justice. Everything must be done to prosecute the perpetrators of atrocity crimes at the ICC; and there is no better time to do it than now.

\section{REFERENCES}

1. United Nations. (2014). Framework of Analysis for Atrocity Crimes - A tool for prevention Available at www.un.org/documant/ 49 last visited 18/1/2021

2. Hastings, M. (2018). "The Hidden Atrocities of the Vietnam War" Wall Street Journal, October 4 Available at www.wsj.com/articles/ the-hiddenatrocities-of-the-vietnam-war-1538664997 last visited 20/1/2021

3. Gittings, J., \& Kettle, M. (2000). "US and S Korea accused of war atrocities" The Guardian 18 January

4. United Nations. (2019). International and Hybrid Criminal Courts and Tribunals Available at un.org/ruleoflaw/ thematic-areas

5. Kebbede, G. (1997). "Sudan: The North-South Conflict in Historical Perspective" Contributions in Black Studies Vol. 15, Article 3 Available at Https://scholarworks.umass.edu/cibs/vol15/iss1/3 last visited 23/3/2020

6. Grant, J.A. (2009). Darfur: Reflections on the Crisis and the Responses Ontario: Centre for International Relations, Queen's University

7. Ottawa, M., \& El-Sadany. (2012). SUDAN: FROM CONFLICT TO CONFLICT, The Carnegie Papers, Carbegie Endowment for International Peace Available at www.carnegieendowment.org/pubs. last visited 23/12/20

8. Sengupta, S. (2016). "Report Accuses Sudan of 'Scorched Earth' Tactics in Darfur" The New York Times available at https://www.nytimes.com/2016/09/29/world>africa last visited 18/2/2020 
James E. Archibong., Sch Int J Law Crime Justice, Mar, 2021; 4(3): 144-150

9. Africa Insiders. (2020). "Africa Insiders: Why Sudan is turning to the ICC to prosecute al-Bashir" Africa Arguments Available at africaarguments.org/2020/02/20 last visited 20/11/2019

10. Aljazeera. (2020). "Who ate those wanted by the ICC over Darfur?" ALJAZEERA Available at www.aljazeera.com/news/2020/2/11 last visited $12 / 1 / 2021$

11. Pogo, S.S. (2009). First Sudanese Civil War Palgrave Macmillan

12. Johnson, D.H. (2016). The Root Causes of Sudan's Civil Wars: Old Wars and New Wars Boydell \& Brewer

13. Momodu, S. (2018). "Second Sudanese Civil War (1983-2005)" Black Past Avalaible at https://www.blackpast.org/global-african last visited 21/3/2020

14. BBC. (2019). "Darfur conflict: Sudan launches investigation into crimes" Available at https://www.bbc.com>news > world-africa last visited 20/11/2019

15. Sikainga, A. (2009). "The World's Worst Humanitarian Crisis: Understanding the Darfur Conflict" Origins Vol. 2, Issue 5 February

16. Prunier, G. (2008). Darfur a $21^{\text {st }}$ Century Genocide, Ithaca, Cornell University Press

17. McFerran, A. (2007). "The Curse of Janjaweed" Sunday Times (London) 23 September

18. Naway, O. (2017). "Voices of Nubia: The victims of al-Bashir's impunity" coalition for the international criminal court www.coalitionfortheicc.org/news/201 last visited 21/1/2020

19. Amnesty International. (2016). "Sudan: Scorched Earth, Poisoned air: Sudanese Government Forces Ravage Jebel Marra, Darfur" AFR54/4877/2016 Available https://www.amnesty.org/en/documents/ last visited 21/12/2019

20. Medecins Sans Frontieres. (2004). "Darfur: A path of scorched earth" Available at https://msf.org/darfur-path-scorched last visited 22/1/2020

21. Amnesty International. (2020). "Sudan: Al-Bashir handover to ICC necessary move for justice for victims" Available at www.amnesty.org/en/latest/news last visited 22/10/2019

22. United Nations. (2005). "Security Council Refers Situation in Darfur, Sudan, to Prosecutor of International Criminal Court" Press Release SC/835/31 March

23. Cohen, R. (2005). "The international Response to Darfur" Forced Migration Review Online Available at https://www.fmreview.org/europe/cohen last visited 21/11/2019
24. United Nations. (2017). "Culture of Impunity Must End for Justice to Prevail in Darfur, International Criminal Court Prosecutor Tells Security Council'" at www.un.org/press/en/2017/sc128 last visited $18 / 2 / 2020$

25. International Federation for Human Rights. (2020). "Will Darfur victims finally see justice? Sudan official announces surrender of Omar al-Bashir to ICC" Press Release Available at www.fidh.org/enregion/Africa/su last visited $12 / 4 / 2020$

26. Amin, M. (2020). "Sudan's Omar al-Bashir to be handed over to ICC" Middle East Eye Available at mddleeasteye.net last visited 23/2/2020

27. Amin, M. (2019). "Sudan's Bashir convicted of corruption, his supporters take to streets" Middle East Eye Available at https:// www.middleeasteye.net/nwes/sudans last visited 20/12/2019

28. Magdy, S. (2020). "Sudan to hand over Omar alBashir for genocide trial, official says" The Washington Times Available at m.washingtontimes.com/news/2020 last visited 23/4/2020

29. BBC. (2020). "Omar al-Bashir: Sudan agrees expresident must face ICC" Available at https://www.bbc.com/news/world-africam last visited 10/4/2020

30. Amnesty International. (2019). "Why former Sudan president Omar al-Bashir must not escape justice" Available at www.amnesty.org/en/latest/news last visited 13/10/2019

31. Becker, S.W. (2010). "The objections of larger nations to the international criminal court" Dans Revue international de droit penal Vol. 81

32. Economist. (2020). "A day of reckoning - Omar alBashir, Sudan's ex-dictator, could at last face justice" Available at https://www.economist.com/middle-east last visited 23/4/2020

33. Associated Press. (2017). "ICC: Failure to arrest Sudan's president undermines court" Available at https://www.foxnews.com/world/icc-failure last visited 12/12/2019

34. REDRESS at redress.org /news/sudans-surrender last visited 25/3/2020

35. Needham, J. (2011). "Protection or Prosecution for Omar Al Bashir? The Changing State of Immunity in International Criminal Law" Auckland University Law Review Vol.17

36. Laing, A. (2016). "South African court attacks government over 'disgraceful' flight of al-Bashir" The Telegraph at https://www.telegraph.co.uk>southafrica last visited 20/2/2020

37. Clarke, J.S. (2015). "South Africa's failure to arrest Omar al-Bashir 'is betrayal of Mandela's ideals" 
James E. Archibong., Sch Int J Law Crime Justice, Mar, 2021; 4(3): 144-150

Available at https://www.theguardian.com/globaldeve last visited 22/11/2019

38. Ncana, N. (2019). "South Africa Revives International Criminal Court Withdrawal Plan" https://www.bloomberg.com/news/article last visited 23/2/2020

39. Keppler, E. (2012). "Managing Setbacks for the International Criminal Court in Africa" Journal of African Law, 56(I).

40. Kahn, N. (2009). "Fighting impunity: The International Criminal Court and the African Union" Centre for Policy Studies Policy Brief 62, September

41. Simonovic, I. (2017). "Responsibility to Protect" UN Chronicle Vol. 53, No. 4

42. Holmes, K.R. (2014). "The Weakness of the Responsibility to Protect as an International Norm" The Heritage Foundation Available at https://www.heritage.org/defense/commentary last visited 23/1/2020

43. Leopold, E. (2005). "France Pushes for UN Vote on Sudan; US May Veto" AlterNet March 24

44. UN News. (2006). Strongly Condemning Escalation of Violence in Sudan, Secretary-General Tells Security Council 'it is Time to Act' 11 September
45. Austin, G., \& Koppelman, B. (2004). Darfur and Genocide: Mechanisms for Rapid Response, An End to Impunity London: The Foreign Centre

46. United Nations. (2018). "Violations of Rome Statute Likely to Continue as States Fail to Arrest Fugitives Indicted over Crimes in Darfur, Chief Prosecutor Warns Security Council" Meetings Coverage sc/13623 14 December Security Council $8425^{\mathrm{TH}} \quad$ Meeting $\quad(\mathrm{PM}) \quad$ at https://www.un.org>sc13623.doc.htm last visited $18 / 2 / 2020$

47. International Criminal Court. (2020). Statement of the Prosecutor of the International Criminal Court, Fatou Bensouda, at a media briefing in Khartoum, Sudan: "There is an urgent need for justice in Sudan. Sustainable peace and reconciliation are built on the stabilizing pillar of justice." Available at www.icc-cpi.int/pages/item.aspx

48. International Centre for Transitional Justice. (2020). "Women's Vigil in Darfur Commemorate Massacres" Available at www.ictj.org/news/women's-vigil-in-darfurcommemorate-massacres last visited 23/1/2021

49. UN News. (2019). Accountability in Sudan 'crucial' to avoid 'further bloodshed' says UN rights office https://news.un.org>story>2019/06 last visited 18/2/2020. 